\title{
The effect of inoculation with mycorrhiza: AM on growth, phenolics, tannins, phenolic composition and antioxidant activity in Valeriana jatamansi Jones
}

\author{
A.K. Jugran, A. Bahukhandi, P. Dhyani, I.D. Bhatt*, R.S. Rawal, S.K. Nandi, L.M.S. \\ Palni
}

1G. B. Pant Institute of Himalayan Environment and Development, Kosi-Katarmal, Almora - 263 643,

Uttarakhand, India. *Corresponding author:idbhatt@gbpihed.nic.in

\begin{abstract}
The mycorrhizal inoculation often reported to increase plant growth and secondary metabolites production, however, little is known on the effect of arbuscular mycorrhizal fungi (AMF) on different growth parameters in Valeriana jatamansi, an important Himalayan medicinal herb. To evaluate mycorrhizal effect, $V$. jatamansi collected from natural population were planted and growth parameters, phytochemicals, antioxidant and phenylalanine ammonia lyase (PAL) activities were determined. Significantly $(p<0.05)$ higher above ground fresh weight (AGFW), above ground dry weight (AGDW), below ground fresh weight (BGFW), below ground dry weight (BGDW) were recorded in plants after the $2^{\text {nd }}$ year. The total phenolics were maximum in aerial $\left[18.03 \pm 0.05\left(1^{\text {st }}\right.\right.$ year $)$ and $10.88 \pm 0.52 \mathrm{mg} \mathrm{GAE} / \mathrm{g}\left(2^{\text {nd }}\right.$ year $\left.)\right]$ and root portions $\left[\left(14.30 \pm 0.04\left(1^{\text {st }}\right.\right.\right.$ year $)$ $7.92 \pm 0.27$ ( $2^{\text {nd }}$ year$\left.)\right]$ of the treated plants as compared to corresponding portions of control plants in both the years. Similarly, the tannin content was higher in treated plants as compared to untreated controls. Variation in different phenolic compounds was also recorded and significantly higher contents of gallic acid, chlorogenic acid, Catechin, and Hydroxy benzoic acid during $1^{\text {st }}$ year was observed. Antioxidant activity of aerial and root pprtion measured by three in vitro assays, showed significant variation $(p<0.05)$ among plants of both the years. Significantly $(p<0.05)$ higher PAL activity was recorded in treated over control plants in $2^{\text {nd }}$ year. The results demonstrated that inoculation with AMF enhances both phenolics and tannins as well as stimulates antioxidant activity suggesting a positive influence of AMF inoculation on yield and for the production of nutraceuticals.
\end{abstract}

Keywords: Arbuscular mycorrhizal fungi (AMF), Phenolics, Tannins, antioxidant activity, Valeriana jatamansi 


\section{Introduction}

Members of the family Valerinaceae are used both in the traditional as well as modern systems of medicine, the activity being attributed to various secondary metabolites, e.g., valepotriates, dihydrovaltrate, linarin-isovalerat, sesquiterpenoids, 6-methylapigenin and hesperidin, and phenolics and flavonoids. One of the highly valued members of this family, Valeriana jatamansi Jones (English name - Indian valerian, Trade name - Tagar), has attracted much attention in recent years. It is a small herb, that grows widely in the temperate Himalaya between 1000$3000 \mathrm{~m}$ above mean sea level (amsl); its roots/rhizomes have been used traditionally for the treatment of many ailments like snake bite, cold and cough; it is also a rich source of phenolics, flavonoids and antioxidants (Kalim et al., 2010; Bhatt et al., 2012; Jugran et al., 2013). Large scale harvesting of this plant continues from the wild to meet the ever growing demand, thereby putting substantial pressure on the natural populations.

Although AMF association with the roots of $V$. jatamansi and some other alpine medicinal herbs has been reported to induce VAM (Vesicular arbuscular mycorrhizae) and hyphal infection, morphological and phytochemical parameters were not examined. The use of AMF to enhance the production of secondary metabolites has been reported (Nell et al., 2010). Recently, it has been indicated that AMF treated Valeriana officinalis plants were successfully colonized and that such plants showed increased sesquiterpenic acid accumulation compared to untreated controls (Nell et al., 2010). AMF also act as biological control agent and are often used in organic farming and play important role in improving the soil fertility and plant nutrition (Banuelos et al., 2014; Caporale et al., 2014; Channabasava et al., 2015).
The biosynthesis of several secondary metabolites, such as carotenoids or lignin, may be mainly constitutive, the synthesis of numerous secondary metabolites like many phenolic compounds, can be induced and enhanced by abiotic and biotic stresses. It is well known that the accumulation of secondary metabolites may increase when plants are undergoing high or low temperatures, high light intensity, UV radiation, drought, mineral deficiencies, salinity or pathogen infection (Baslam et al., 2013). A possible mechanism of increased phytochemical concentration in plants could be through improved nutrition. Amino acids like tyrosine and phenylalanine are important precursors to the production of various phenolics compound like rosmerinic acid and caffeic acid (Petersen and Simmonds, 2003). Therefore it could be possible that higher $\mathrm{N}$ assimilation in AM plants (Toussaint et al., 2004) might contribute in the production of these amino acids, which subsequently stimulate higher production of the phenylalanine ammonia lyase, one of the main enzyme involved in the production of various phenolic compounds. Another possible mechanism could be the changes induced by AMF in the level of phytohormone such as cytokinin or gibberellin (Allen et al., 1980). However, there possibilities are needed to be checked.

Phenolics are one of the major compounds which impart antioxidant activity in plants, and their biosynthesis involves the induction of phenylalanine ammonia lyase (PAL, EC 4.3.1.5), the first rate limiting enzyme in the phenyl propanoid metabolism (Rhodes, 1985). The accumulation of phenolics and other secondary metabolites in plant tissues has been known to be induced by abiotic stresses as well as by fungal infection (Zhi-Lin et al., 2007). Therefore, there exists a potential for increased production of phytochemicals for developing commercial health 
care products. As such, the influence of mycorrhizal inoculation on secondary metabolite production in Himalayan medicinal herbs has not been reported. Realizing this, the present investigation was undertaken using a highly valued medicinal herb, $V$. jatamansi, to assess the effect of mycorrhizal inoculation on (i) growth performance, (ii) secondary metabolites like total phenolics, tannins content, antioxidant activity, and (iii) establish relationship of phenylalanine ammonia lyase (PAL) with secondary metabolites in $V$. jatamansi.

\section{Materials and Methods}

\subsection{Screening of fungus in natural plants of $V$. jata-} mansi

Young growing plants (10 Nos.) were randomly collected from its natural population from Katarmal. Rhizomes/roots of each plant were washed in deionized water and cut into $\sim 1 \mathrm{~cm}$ segment and cleared in $10 \% \mathrm{KOH}$ for two days at room temperature, rinsed several times with distilled water and stained with 5\% ink- vinegar solution (Blank ink, Shaeffer) for $30 \mathrm{~min}$ at $80^{\circ} \mathrm{C}$. The rhizomes were subsequently distained with acidified water (using few drops of vinegar). Colonization was determined using magnified interaction method with minor modification (Cavagnaro et al., 2001).

Rhizome/root pieces mounted on slides were examined at x100 magnification using light microscope. One hundred interactions between rhizome and crosshair were observed for presence or absence of AM structure (internal and external hyphae; arbuscules and/or vesicles). As no fungal growth was observed in the plants therefore the plants from this site was used for further experimentation.

\subsection{Plant and fungal material}

Young growing plants (120 Nos.) of $V$. jatamansi Jones were taken from their natural population in Katarmal forest, Almora, India (Lat. 29 38' N, Long. $79^{\circ} 36^{\prime} \mathrm{E}$, altitude $1200 \mathrm{~m}$ above mean sea level) and planted in the experimental plot at Surya Kunj - Nature Interpretation and Learning Center of G. B. Pant Institute of Himalayan Environment and Development, Kosi - Katarmal, Almora, India (Lat. 29 ${ }^{\circ} 46^{\prime}$ $\mathrm{N}$, Long. $79^{\circ} 35^{\prime} \mathrm{E}$; altitude $1150 \mathrm{~m}$ asl). The AMF preparation used in the present study was a consortia of three different isolates of Glomus intradices spp. (Tiwari and Adholeya, 2002) prepared and marketed by Majestic Agronomic Pvt. Ltd., Himachal Pradesh, India with brand name Mycorrhiza - AM. The Mycorrhiza-AM was a gift from Prof. Y. K. Bhoon (Sri Venkateswara College, New Delhi). The experimental plot was subdivided into 6 subplots $(2 \mathrm{X} 2 \mathrm{~m}) ; 3$ subplots (size $12 \mathrm{~m}^{2}$ each; total plot size $24 \mathrm{~m}^{2}$ ) were used for growing control plants (i.e., without AMF inoculation) and the remaining 3 subplots were used for growing treated plants (20 plants/subplot). Plants growing in the control plots were treated with farmyard manure (4 kg/plot), while the plants growing in the treatment subplots were inoculated with AMF (400 g per dose) and the same amount of farmyard manure $(4 \mathrm{Kg} /$ plot $)$. The treated plants of $1^{\text {st }}$ year received two doses of inoculant, while plants in the $2^{\text {nd }}$ year received 3 doses of inoculant. At the end of $1^{\text {st }}$ year 60 plants (30 control and 30 treated ones) were harvested to record morphological parameters and for the determination of total phenolics, tannins and antioxidant activity. Remaining 60 plants were harvested at the end of $2^{\text {nd }}$ year and all parameters, as in the first year, were recorded. The phenylalanine ammonia lyase (PAL) was, however, determined in the $2^{\text {nd }}$ year plants only. 


\subsection{Morphological analyses}

Various morphological parameters like leaf number (LN), leaf area (LA), plant height (PH), above and below ground fresh (AGFW and BGFW) and dry weight (AGDW and BGDW), rhizome length (RL) and width (RW), etc., were recorded for each individual. Leaf length and width of each plant was determined using 2 mature leaves per plant. AGFW and BGFW was recorded using electronic balance (Afcoset, India) and dry weight was determined after drying samples in an oven $\left(40{ }^{\circ} \mathrm{C}\right.$ till constant weight). RL and RW were measured using digital Vernier callipers (Mitutoya, Japan).

\subsection{Extract preparation}

Aerial and root portions of each plant were separately collected and washed first with running tap water and then with distilled water, dried (hot air oven, $40{ }^{\circ} \mathrm{C}$ ) and ground into fine powder. Dried powder $(1.0 \mathrm{~g})$ was mixed with $25 \mathrm{ml}$ aqueous methanol $(80 \%$, v/v); the suspension was stirred gently $(12 \mathrm{~h})$ and then sonicated $\left(22^{\circ} \mathrm{C}, 10 \mathrm{~min}\right.$; Model-ANIS 09001, Toshiba, New Delhi, India). The extract was centrifuged $\left(10,000 \mathrm{rpm} ; 15 \mathrm{~min}, 22^{\circ} \mathrm{C}\right)$ and the supernatants was collected, filtered and stored at $4{ }^{\circ} \mathrm{C}$ prior to use for analyses within $24 \mathrm{~h}$.

\subsection{Determination of total phenolic content}

Total phenolic content in the methanolic extract of root and aerial portions was determined by Folin-Ciocalteu's colorimetric method (Singleton and Rossi, 1965). The extract $(0.25 \mathrm{ml})$ was diluted with distilled water $(2.25 \mathrm{ml})$ and then mixed with Folin-Ciocalteu's reagent $(0.25 \mathrm{ml})$. After $5 \mathrm{~min}$, this mixture was neutralized by adding $2.5 \mathrm{ml}$ of sodium carbonate $(7 \%, \mathrm{w} / \mathrm{w})$ and allowed to stand in the dark $\left(22 \pm 1^{\circ} \mathrm{C}\right.$,
$90 \mathrm{~min})$. The absorbance of resultant blue color was measured at $765 \mathrm{~nm}$ using UV-VIS spectrophotometer (U-2001, Hitachi, Japan). The quantification of total phenolics was done on the basis of standard curve of gallic acid prepared in aqueous methanol $(80 \%$, $\mathrm{v} / \mathrm{v}$ ), and the results were expressed in $\mathrm{mg}$ gallic acid equivalent (GAE)/g dry weight.

\subsection{Determination of total tannin content}

This was estimated following the method of Nwinuka et al. (2005) with minor modifications. Methanolic extract $(5 \mathrm{ml})$ was added to Folin-Dennis reagent $(0.5 \mathrm{ml})$ and saturated with $1 \mathrm{ml}$ sodium carbonate solution. The solution was diluted up to $10 \mathrm{ml}$ with distilled water and allowed to stand $\left(22 \pm 1^{\circ} \mathrm{C}, 20 \mathrm{~min}\right)$. The absorbance of resulting greenish blue color was measured at $700 \mathrm{~nm}$, and the quantification of total tannins was done on the basis of standard curve of tannic acid prepared in aqueous methanol $(80 \%, \mathrm{v} / \mathrm{v})$. Results were expressed in $\mathrm{mg}$ tannic acid equivalent (TAE)/g dry weight.

\subsection{HPLC analysis of phenolic compounds}

High Performance Liquid Chromatography (HPLC) analysis was carried out on a Merck Hitachi HPLC system equipped with L-7100 series pump, L-7400 series detector, $4.6 \mathrm{~mm} \times 250 \mathrm{~mm}$ i.d., $5 \mu \mathrm{m}$, Purospher ${ }^{\circledR}$, and C-8 column (Merck Pvt Ltd., Germany). The mobile phase water: methanol: acetic acid (80:20:1 and 70:30:1 ratio) with $0.8 \mathrm{ml} / \mathrm{min}$ flow rate and $20 \mu 1$ injection volume was used for isolation of phenolics and flavonoids. The compounds spectra were recorded at different wavelengths [(i.e., gallic acid, catechin and hydroxybenzoic acid $(254 \mathrm{~nm})$, and chlorogenic acid $(370 \mathrm{~nm})]$. The concentration of phenolic acid and flavonoids were calculated with the help of a corresponding external standard and results expressed in $\mathrm{mg} / 100 \mathrm{~g}$ dry weight. 


\subsection{Estimation of antioxidant activity}

Total antioxidant activity was measured by improved ABTS (ethyl benzothiazoline, 6-sulphonic) method (Cai et al., 2004). ABTS $(7.0 \mu \mathrm{M})$ and potassium persulphate $(2.45 \mu \mathrm{M})$ were added in an amber colored bottle for the production of $\mathrm{ABTS}$ cation $\left(\mathrm{ABTS}^{\circ}+\right)$ and kept in the dark for $\left(16 \mathrm{~h}, 22 \pm 1^{\circ} \mathrm{C}\right)$. ABTS ${ }^{\circ}$ solution was diluted with ethanol $(80 \%, \mathrm{v} / \mathrm{v})$ till an absorbance of $0.700 \pm 0.05$ at $734 \mathrm{~nm}$ was obtained. For sample analysis $3.90 \mathrm{ml}$ of diluted $\mathrm{ABTS}^{\circ}+$ solution was added to $0.10 \mathrm{ml}$ of methanolic extract. The resulting solution was mixed thoroughly and allowed to stand for $6 \mathrm{~min}$ in the dark at $22 \pm 1^{\circ} \mathrm{C}$. Absorbance was recorded at $734 \mathrm{~nm}$ using UV-VIS spectrophotometer. Samples were diluted with aqueous methanol $(80 \%, \mathrm{v} / \mathrm{v})$ to obtain $20-80 \%$ reduction in absorbance at $734 \mathrm{~nm}$ with respect to blank. A standard curve using various concentrations of ascorbic acid in aqueous methanol $(80 \%, \mathrm{v} / \mathrm{v})$ was prepared for the quantification of antioxidant potential. Results were expressed in millimole $(\mathrm{mM})$ ascorbic acid equivalent (AAE)/100 g dry weight.

Study followed traditional DPPH (2, 2- diphenyl1-picryylhydrazyl) cations assay (Brand-William et al., 1995) with minor modifications. Equal volume of $400 \mathrm{mM}$ DPPH, 0.2M MES buffer ( $\mathrm{pH} 6.0$ adjusted with $\mathrm{NaOH})$ and ethanol $(20 \%$, v/v) was added to the mixture. DPPH cation solution $(2.7 \mathrm{ml})$ was mixed with sample extract $(0.9 \mathrm{ml})$ and kept in the dark at room temperature $\left(22 \pm 1^{\circ} \mathrm{C}\right)$ for $20 \mathrm{~min}$. Absorbance was recorded at 520nm using UV-VIS spectrophotometer. Results were expressed in $\mathrm{mM}$ AAE/100 g dry weight.

Ferric reducing antioxidant power (FRAP) assay was performed using the method of Faria et al. (2005) with minor modifications. FRAP reagent was prepared by adding $300 \mathrm{mM}$ acetate buffer $(100 \mathrm{ml})$ (i.e., $3.1 \mathrm{~g}$ sodium acetate and $16 \mathrm{ml}$ glacial acetic acid/l);
$10 \mathrm{mM} \mathrm{2,} \mathrm{4,} \mathrm{6-tri-2-pyridyl-} \mathrm{1,} \mathrm{3,} \mathrm{5-triazin} \mathrm{(TPTZ)}$ in $40 \mathrm{mM}$ HCL $(10 \mathrm{ml}) ; 20 \mathrm{mM}$ ferric chloride $(10$ $\mathrm{ml})$. The mixture was pre - warmed at $37{ }^{\circ} \mathrm{C}$ in water bath (Labtech, Korea) and $3.0 \mathrm{ml}$ of the mixture was added to $0.1 \mathrm{ml}$ methanolic extract and kept at $37{ }^{\circ} \mathrm{C}$ for $8 \mathrm{~min}$. Absorbance was then recorded at $593 \mathrm{~nm}$. A blank sample was prepared using ascorbic acid and the results were expressed in mM AAE/100 g dry weight.

\subsection{Phenylalanine ammonia lyase (PAL) estimation}

PAL activity was estimated using the method of Zucker et al. (1968) with following modifications. Freshly harvested aerial and root portions $(500 \mathrm{mg})$ were homogenized in $5 \mathrm{ml}$ of ice cold $0.1 \mathrm{M}$ sodium borate buffer ( $\mathrm{pH} 8.8$ ) containing $1.4 \mathrm{mM}$ of 2-mercaptoethanol. The extract was filtered through Whatman filter paper (No. 42) and the filtrate was centrifuged $\left(15,000 \mathrm{rpm}, 4{ }^{\circ} \mathrm{C}, 15 \mathrm{~min}\right)$. The supernatant was used as enzyme source. PAL activity was determined as the rate of conversion of L-phenylalanine to trans-cinnamic acid at $290 \mathrm{~nm}$.

Samples containing $0.3 \mathrm{ml}$ of enzyme extract were incubated with $0.5 \mathrm{ml}$ of $0.1 \mathrm{M}$ borate buffer, $\mathrm{pH} 8.8$ and $0.5 \mathrm{ml}$ of $12 \mathrm{mM} \mathrm{L}$-phenylalanine in the same buffer for $30 \mathrm{~min}$ at $40{ }^{\circ} \mathrm{C}$. The amount of transcinnamic acid formed was calculated as micromoles of trans-cinnamic acid using a standard curve developed for trans-cinnamic acid, and expressed as $\mathrm{Ug}^{-1}$ fw ( $\mu$ moles trans-cinnamic acid $\min ^{-1} \mathrm{mg} \mathrm{fw}^{-1}$ ). One unit of PAL was defined as the formation of 1 $\mu \mathrm{M}$ cinnamic acid per hour.

\subsection{Statistical analysis}

All determinations of antioxidant activity by ABTS, DPPH, FRAP assays and the measurements of total phenols and tannins were conducted using 4 replicates. 
The value for each sample was calculated as the mean \pm SE Statistical analyses [paired sample $t$ test and Pearson correlation coefficients (r)] were carried out using Microsoft Excel 2007 and SPSS version 7.5.

\section{Results}

\subsection{Morphological variations}

Variations in the morphological parameters of control and treated plants have been shown (Table 1). Significant $(p<0.05)$ variations were observed in respect of RW $(\mathrm{t}=11.59, p<0.01)$ and $\mathrm{RL}(\mathrm{t}=9.9, p<0.01)$ of the $1^{\text {st }}$ year treated and control plants. The $1^{\text {st }}$ year control plants showed higher values for all morphological parameter as compared to treated ones except for RL. Similar results were obtained in the $2^{\text {nd }}$ year plants for all morphological parameters except for $\mathrm{LN}$ and $\mathrm{PH}$ that showed higher values in treated ones. However, except for RL ( $\mathrm{t}=3.53 ; p<0.01)$, BGFW $(\mathrm{t}=$ $2.57 ; p<0.01)$, and BGDW ( $\mathrm{t}=2.97 ; p<0.01)$ no significant differences were recorded in morphological parameters between control and treated plants of $2^{\text {nd }}$ year. The comparison between $1^{\text {st }}$ and $2^{\text {nd }}$ year control plants revealed significant difference in AGFW ( $\mathrm{t}=$ 3.90; $p<0.00)$, BGFW ( $\mathrm{t}=4.47 ; p<0.01)$, LL $(\mathrm{t}=2.42$; $p<0.01)$, LW $(\mathrm{t}=3.54 ; p<0.01)$, LA $(\mathrm{t}=3.33 ; p<0.01)$ (Table 1). Whereas the comparison between $1^{\text {st }}$ and $2^{\text {nd }}$ year treated plants exhibited significant difference in all morphological parameters, except LN, LL and LW.

Table 1. Comparative analysis of morphological parameters of control and AMF treated plants of V. jatamansi.

\begin{tabular}{|c|c|c|c|c|c|c|c|c|}
\hline \multirow{2}{*}{$\begin{array}{l}\text { Morphological } \\
\text { parameters }\end{array}$} & \multicolumn{2}{|c|}{$1^{\text {st }}$ year plants } & \multirow[t]{2}{*}{ t value } & \multicolumn{2}{|c|}{$2^{\text {nd }}$ year plants } & \multirow[t]{2}{*}{$t$ value } & \multirow{2}{*}{$\begin{array}{c}\text { t value } \\
\text { between } 1^{\text {st }} \\
\text { and } 2^{\text {nd }} \text { year } \\
\text { control } \\
\text { plants }\end{array}$} & \multirow{2}{*}{$\begin{array}{c}t \text { value between } \\
1^{\text {st }} \text { and } 2^{\text {nd }} \text { year } \\
\text { treated plants }\end{array}$} \\
\hline & Control & Treated & & Control & Treated & & & \\
\hline $\mathrm{LN}$ & $20.63 \pm 1.7$ & $18.23 \pm 1.19$ & $\mathrm{~ns}$ & $20.23 \pm 1.51$ & $22.57 \pm 2.44$ & ns & $\mathrm{ns}$ & ns \\
\hline $\mathrm{LL}(\mathrm{cm})$ & $3.25 \pm 0.14$ & $3.43 \pm 0.10$ & ns & $3.70 \pm 0.14$ & $3.91 \pm 0.34$ & ns & $2.42 *$ & ns \\
\hline $\mathrm{LW}(\mathrm{cm})$ & $3.07 \pm 0.14$ & $3.44 \pm 0.10$ & ns & $3.76 \pm 0.19$ & $3.83 \pm 0.26$ & ns & $3.54^{* * *}$ & ns \\
\hline $\mathrm{LA}(\mathrm{cm} 2)$ & $9.98 \pm 0.02$ & $11.82 \pm 0.01$ & $\mathrm{~ns}$ & $13.92 \pm 0.03$ & $14.98 \pm 0.09$ & ns & $3.33^{\text {*** }}$ & $2.48^{*}$ \\
\hline $\mathrm{RW}(\mathrm{cm})$ & $10.53 \pm 0.4$ & $3.52 \pm 0.33$ & $11.59 * *$ & $5.50 \pm 0.39$ & $4.83 \pm 0.30$ & ns & ns & $2.93 * *$ \\
\hline $\mathrm{RL}(\mathrm{cm})$ & $4.87 \pm 0.33$ & $11.00 \pm .51$ & $9.92 * *$ & $4.82 \pm 0.30$ & $4.97 \pm 0.29$ & $3.53^{* * *}$ & ns & $19.88 * *$ \\
\hline AGFW (g) & $6.20 \pm 0.52$ & $5.72 \pm 0.54$ & ns & $12.99 \pm 1.56$ & $12.33 \pm 1.38$ & ns & $3.90^{* *}$ & $4.54^{* * *}$ \\
\hline AGDW (g) & $0.76 \pm 0.06$ & $0.74 \pm 0.08$ & ns & $1.52 \pm 0.15$ & $1.65 \pm 0.13$ & ns & ns & $7.70^{* * *}$ \\
\hline BGFW (g) & $8.47 \pm 0.81$ & $7.00 \pm 0.79$ & ns & $16.04 \pm 1.43$ & $12.18 \pm 1.57$ & $2.57 * *$ & $4.47 * *$ & $2.77 * *$ \\
\hline BGDW (g) & $1.60 \pm 0.15$ & $1.45 \pm 0.16$ & ns & $3.56 \pm 0.45$ & $2.93 \pm 0.37$ & $2.97 * *$ & ns & $9.06 * *$ \\
\hline $\mathrm{PH}(\mathrm{cm})$ & $6.57 \pm 0.45$ & $5.76 \pm 0.29$ & ns & $7.31 \pm 0.42$ & $7.98 \pm 0.66$ & ns & ns & $2.99^{* * *}$ \\
\hline
\end{tabular}

Level of significance: $* p<0.05 ; * * p<0.01$

LN, Leaf Number; LL, leaf length; LW, leaf width; LA; leaf area; RW, rhizome width; RL, rhizome length; AGFW, above ground fresh weight; AGDW, above ground dry weight; BGFW, below ground fresh weight; BGDW, below ground dry weight; $\mathrm{PH}$, plant height 

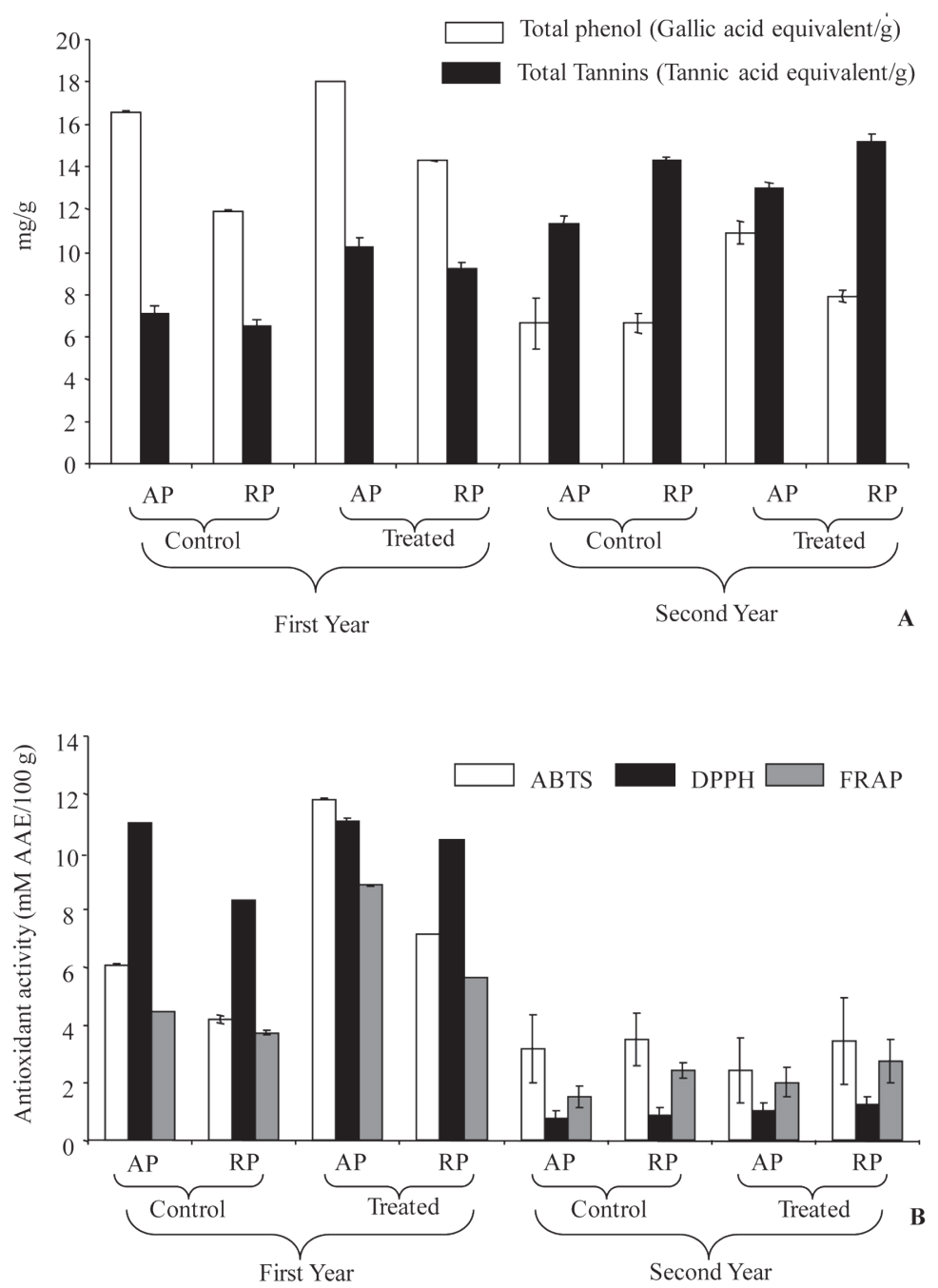

Figure 1. Variation in phytochemicals and antioxidant activity in control and treated plants of $V$. jatamansi in 2 successive years; A- total phenolics and tannin content; B- antioxidant activity by ABTS, DPPH and FRAP assays [AP, aerial portion; RP, root portion; ABTS, 2, 2'-azino-bis (3-ethylbenzothiazoline-6-sulphonic acid); DPPH, 2, 2- diphenyl-1-picryylhydrazyl; FRAP, Ferric reducing antioxidant power activity].

$\mathrm{t}$ value for the $1^{\text {st }}$ year - Aerial portion- ABTS $\left(\mathrm{t}=-0.15^{\mathrm{ns}}\right)$; DPPH $\left(\mathrm{t}=-16.95^{*}\right)$; FRAP $\left(\mathrm{t}=-9.21^{*}\right.$; Root portion -ABTS $\left(\mathrm{t}=6.75^{*}\right)$; DPPH $\left(\mathrm{t}=-10.35^{*}\right)$; FRAP $\left(\mathrm{t}=4.87^{*}\right) ; 2^{\text {nd }}$ year- Aerial portion- ABTS $\left(\mathrm{t}=3.17^{*}\right)$; DPPH $(\mathrm{t}$ $\left.=7.31^{*}\right) ; \operatorname{FRAP}\left(\mathrm{t}=1.60^{\mathrm{ns}}\right) ;$ Root portion- $\operatorname{ABTS}\left(\mathrm{t}=1.41^{\mathrm{ns}}\right) ; \mathrm{DPPH}\left(\mathrm{t}=6.23^{*}\right) ; \operatorname{FRAP}\left(\mathrm{t}=0.87^{\mathrm{ns}}\right)$ 


\subsection{Variation in the total phenolic and tannin con-} tents

Higher total phenolic content was recorded in control and treated plants of $1^{\text {st }}$ year as compared to values recorded for $2^{\text {nd }}$ year plants (Figure 1A). Total phenolic content of $1^{\text {st }}$ year plants was higher in aerial $(18.03 \pm$ $0.051^{\text {st }}$ year and $10.88 \pm 0.52 \mathrm{mg} \mathrm{GAE} / \mathrm{g} 2^{\text {nd }}$ year) and root portions $\left(14.30 \pm 0.041^{\text {st }}\right.$ year and $7.92 \pm 0.27 \mathrm{mg}$ $\mathrm{GAE} / \mathrm{g} 2^{\text {nd }}$ year) of treated plants as compared to controls (aerial $1^{\text {st }}$ year- $16.61 \pm 0.04 ; 2^{\text {nd }}$ year: $6.63 \pm 1.20$, and roots $1^{\text {st }}$ year $-11.94 \pm 0.03 ; 2^{\text {nd }}$ year $-6.66 \pm 0.48 \mathrm{mg}$ $\mathrm{GAE} / \mathrm{g}$ ); however, the quantity was higher in the aerial portion. Similarly, the tannin content was recorded to be higher in both aerial $\left[10.26 \pm 0.40\left(1^{\text {st }}\right.\right.$ year $)$ and
$12.99 \pm 0.26 \mathrm{mg} \mathrm{TAE} / \mathrm{g}\left(2^{\text {nd }}\right.$ year $\left.)\right]$ and root portions $\left[9.21 \pm 0.27\left(1^{\text {st }}\right.\right.$ year $)$ and $15.18 \pm 0.41 \mathrm{mg} \mathrm{TAE} / \mathrm{g}\left(2^{\text {nd }}\right.$ year)] of treated plants as compared to control (Figure 1A). Comparison between $1^{\text {st }}$ and $2^{\text {nd }}$ year plants (control and treated) revealed significantly higher tannin content in plants of $2^{\text {nd }}$ year (Figure 1A). However, phenolics in aerial and root portions of treated and control plants of $2^{\text {nd }}$ year did not reveal significant difference $(\mathrm{t}=1.503, p<0.17)$. Similarly, tannin content in root portion of treated and control plants of $2^{\text {nd }}$ year did not show significant $(\mathrm{t}=0.96, p<0.36)$ difference. However, significant $(\mathrm{t}=3.35, p<0.01)$ difference was found in respect of tannin content of aerial portions of $2^{\text {nd }}$ year treated and control plants.

Table 2. Phenolic composition identified in control and treated plants of $V$. jatamansi

\begin{tabular}{|c|c|c|c|c|c|}
\hline & $\begin{array}{l}\text { Plant } \\
\text { portion }\end{array}$ & Control & Treated & $\mathrm{t}$ & $p$ \\
\hline \multicolumn{6}{|l|}{$1^{\text {st }}$ Year } \\
\hline \multicolumn{6}{|c|}{ Gallic acid } \\
\hline \multirow{4}{*}{$2^{\text {nd }}$ Year } & Aerial & $10.76 \pm 1.47$ & $67.67 \pm 0.87$ & -25.030 & $0.002 * *$ \\
\hline & Roots & $22.66 \pm 5.46$ & $14.99 \pm 2.56$ & -2.563 & 0.124 \\
\hline & Aerial & $13.90 \pm 0.85$ & $13.98 \pm 0.85$ & 0.98 & 0.430 \\
\hline & Root & $21.06 \pm 1.32$ & $23.91 \pm 0.56$ & -1.72 & 0.228 \\
\hline \multicolumn{6}{|c|}{ Chlorogenic acid } \\
\hline \multirow[t]{2}{*}{$1^{\text {st }}$ Year } & Aerial & $311.95 \pm 3.45$ & $404.19 \pm 72.09$ & -1.988 & 0.185 \\
\hline & Roots & $41.15 \pm 13.42$ & $51.89 \pm 0.16$ & -2.753 & 0.110 \\
\hline \multirow[t]{2}{*}{$2^{\text {nd }}$ Year } & Aerial & $264.37 \pm 5.68$ & $264.37 \pm 5.68$ & 0.700 & 0.556 \\
\hline & Root & $111.58 \pm 10.83$ & $92.80 \pm 15.33$ & -0.802 & 0.502 \\
\hline \multicolumn{6}{|l|}{ Catechin } \\
\hline \multirow[t]{2}{*}{$1^{\text {st }}$ Year } & Aerial & $6.76 \pm 0.58$ & $16.29 \pm 1.96$ & -9.699 & $0.010^{* *}$ \\
\hline & Roots & $12.90 \pm 0.89$ & $19.47 \pm 1.19$ & -13.160 & $0.006^{* *}$ \\
\hline \multicolumn{6}{|l|}{$2^{\text {nd }}$ Year } \\
\hline & Roots & $13.84 \pm 0.59$ & $16.06 \pm 0.11$ & 3.202 & 0.085 \\
\hline \multicolumn{6}{|c|}{ Hydroxy benzoic acid } \\
\hline \multirow[t]{2}{*}{$1^{\text {st }}$ Year } & Aerial & $313.80 \pm 1.69$ & $358.71 \pm 109.14$ & -0.992 & 0.426 \\
\hline & Roots & $45.95 \pm 6.07$ & $51.89 \pm 0.16$ & -1.021 & 0.415 \\
\hline \multicolumn{6}{|l|}{$2^{\text {nd }}$ Year } \\
\hline & Aerial & $360.53 \pm 29.80$ & $381.53 \pm 0.41$ & -0.479 & $0.042 *$ \\
\hline & Roots & $88.60 \pm 14.92$ & $111.80 \pm 10.60$ & -0.675 & 0.569 \\
\hline
\end{tabular}

Level of significance: $* p<0.05 ; * * p<0.01$ 


\subsection{Phenolic composition}

Significantly $(p<0.05)$ higher gallic acid $(67.67 \pm 0.87$ $\mathrm{mg} / 100 \mathrm{~g} \mathrm{dw}$ ) content was detected in first year treated plants as compared to control plants in aerial portion while in case of root portion it was lower $(14.99 \pm 2.56$ $\mathrm{mg} / 100 \mathrm{~g} \mathrm{dw}$; Table 2 ). However in case of $2^{\text {nd }}$ year plants it was non-significantly higher in aerial $(13.98 \pm 0.85)$ and root portion $(23.91 \pm 0.56 \mathrm{mg} / 100$ $\mathrm{g} \mathrm{dw}$ ) of treated plants. In case of chlorogenic acid higher value was recorded in aerial and root portion of treated plants of first year. In case of $2^{\text {nd }}$ year plants aerial portion exhibits higher value in control plants but root portion of treated showed non-significant higher value. Catechin content was significantly ( $p<$ $0.01)$ higher $(16.29 \pm 1.96 \mathrm{mg} / 100 \mathrm{~g} \mathrm{dw})$ in aerial and root portion $(19.47 \pm 1.19 \mathrm{mg} / 100 \mathrm{~g} \mathrm{dw})$ of first year treated plants. While in case of 2 nd year plants no significant variations was recorded in control and treated plants. Although Hydroxy benzoic acid content was higher in aerial and root portion of 1 st and $2^{\text {nd }}$ year treated plants but the variations were non-significant.

\subsection{Antioxidant activity}

Antioxidant activity in aerial and root portions of $V$. jatamansi, measured by three in vitro assays, showed a significant difference $(p<0.05)$ among plants of both the years. Results revealed that treated plants exhibited higher antioxidant activity over control plants (Figure 1B). Significant increase $(p<0.05)$ was found in antioxidant activity measured by ABTS and FRAP assays. Comparison between $1^{\text {st }}$ year control and treated plants revealed difference (control aerial vs treated aerial and control roots vs treated roots) by all assays except ABTS in aerial portion. In case of $2^{\text {nd }}$ year plants, significant differences were recorded by DPPH assay in aerial $(\mathrm{t}=7.31, p<0.01)$ and root portions $(\mathrm{t}=6.23, p<0.01)$ of treated and control plants.
Both the treated and control plants also showed significant difference in ABTS activity in aerial portion $(\mathrm{t}$ $=3.17, p<0.01$ ). Higher antioxidant activity (ABTS$11.83 \pm 0.02$, DPPH- $11.07 \pm 0.10$, FRAP- $8.85 \pm 0.01$ $\mathrm{mM} \mathrm{AAE} / 100 \mathrm{~g} \mathrm{dw}$ ) was, however, recorded in aerial portion of treated over control plants of the $1^{\text {st }}$ year. Similarly, antioxidant activity measured by DPPH $(1.06 \pm 0.90 \mathrm{mM} \mathrm{AAE} / 100 \mathrm{~g} \mathrm{dw})$ and FRAP $(2.02 \pm 0.25$ $\mathrm{mM} \mathrm{AAE} / 100 \mathrm{~g} \mathrm{dw}$ ) assays was higher in aerial portion of treated plants of $2^{\text {nd }}$ year, but lower $(2.43 \pm 0.28$ mM AAE $/ 100 \mathrm{~g} \mathrm{dw}$ ) in ABTS assay. Invariably, higher antioxidant activity was recorded in the root portions of treated as compared to control plants.

\subsection{PAL activity}

Lower PAL activity was recorded in aerial $(11.06 \pm 1.78$ $\left.\mathrm{Ug}^{-1} \mathrm{fw}\right)$ and root portions $\left(6.47 \pm 0.43 \mathrm{Ug}^{-1} \mathrm{fw}\right)$ of control plants, while in treated plants, roots exhibited higher (17.12 $\left.\pm 6.24 \mathrm{Ug}^{-1} \mathrm{fw}\right)$ PAL activity as compared to aerial portion $\left(11.84 \pm 1.68 \mathrm{Ug}^{-1} \mathrm{fw}\right.$; Figure 2). The variations of PAL activity between control and treated plants across plant parts was not significant (aerial: $\mathrm{t}=$ $0.54, p<0.59$; roots: $\mathrm{t}=1.85, p<0.09$ ).

\subsection{Relationship among morphological and phyto- chemical attributes}

Various relationships have been depicted in case of $1^{\text {st }}$ year control plants for different morphological and phytochemical parameters (Table 3). AGFW showed positive relationship with AGDW $(r=0.85)$ and $\mathrm{PH}(\mathrm{r}=0.70)$. There were positive relationships with AGDW and PH $(r=0.60 ; p<0.05)$ and between BGFW and BGDW ( $\mathrm{r}=0.97 ; p<0.05)$. TP (aerial portion) showed positive relationship with DPPH (aerial portion; $r=0.88$ ). FRAP (aerial portion) showed positive relationship with TP (aerial portion; $r=0.44$ ). DPPH (aerial portion) showed positive relationship 
with FRAP $(r=0.62)$ and ABTS $(r=0.54)$ aerial portion. TP (aerial portion) showed positive relationship with DPPH aerial portion $(r=0.88)$. However, in control plants of $2^{\text {nd }}$ year only DPPH (aerial portion) exhibited significant positive $(p<0.05)$ relationship with DPPH (root portion; $r=0.92$ ).

In treated plants, significant relationships were found among different morphological parameters of $1^{\text {st }}$ year treated plants (Table 4); AGFW showed significant positive relationship with AGDW $(\mathrm{r}=0.66)$, BGFW $(\mathrm{r}=0.82)$, BGDW $(\mathrm{r}=0.78)$, and $\mathrm{PH}(\mathrm{r}=0.62)$. AGDW exhibited positive relationship with BGFW ( $\mathrm{r}$ $=0.60)$ and BGDW $(\mathrm{r}=0.60)$. BGFW also showed positive relationship with BGDW $(r=0.90)$, and $\mathrm{PH}$ $(\mathrm{r}=0.52)$. Among different phytochemicals analyzed in the aerial and root portions of treated plants, FRAP (aerial portion) showed significant $(p<0.05)$ positive relationship with TP (aerial portion; $r=0.66$ ). Similarly, ABTS (root portion) showed positive relationship with TP (aerial portion; $r=0.53$ ). TP (root portion) showed positive relationship with FRAP (root portion; $r=0.72$ ); DPPH (root portion) showed positive relationship with FRAP (root portion; $r=0.80$ ). However, in treated plants of $2^{\text {nd }}$ year only TP (aerial portion) showed significant positive $(p<0.05)$ relationship with TP (root portion; $r=0.83$ ).

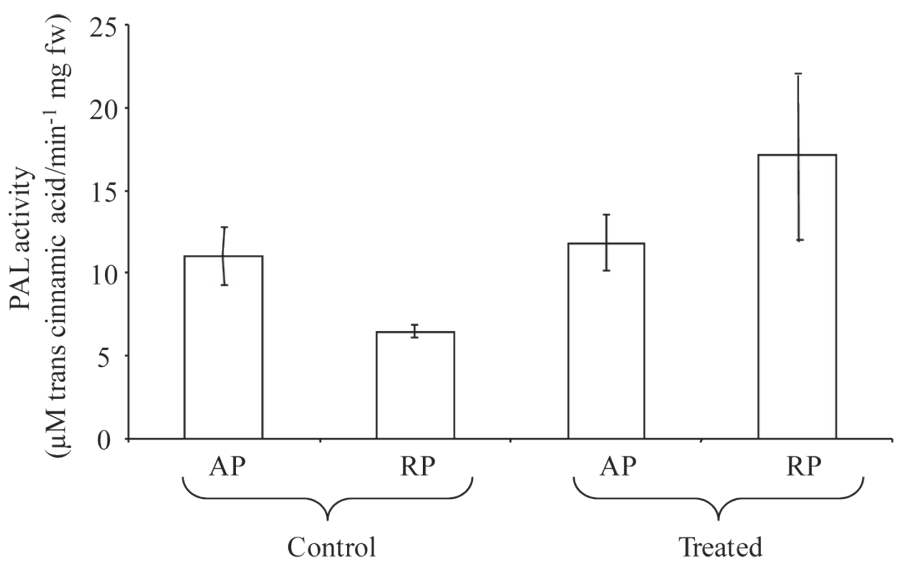

Plant portions

Figure 2. Variation in Phenylalanine ammonia lyase (PAL) activity in control and treated plants of $V$. jatamansi after 2 years of cultivation.

$\mathrm{t}$ value for the $1^{\text {st }}$ year - Aerial portion- Total phenolics - TP $\left(\mathrm{t}=-1.84^{\mathrm{ns}}\right)$; Tannins $\left(\mathrm{t}=3.35^{*}\right)$; Root portion - TP $\left(\mathrm{t}=-4.51^{*}\right)$; Tannins $\left(0.97^{\mathrm{ns}}\right) ; 2^{\text {nd }}$ year - Aerial portion $-\mathrm{TP}\left(\mathrm{t}=1.50^{\mathrm{ns}}\right)$; Tannins $\left(\mathrm{t}=3.35^{*}\right)$; Root portion $-\mathrm{TP}(\mathrm{t}=$ $\left.-2.021^{\mathrm{ns}}\right)$; Tannins $\left(0.96^{\mathrm{ns}}\right)$ 
Table 3. Relationship (Pearson Correlation) among morphological and phytochemical parameters of $1^{\text {st }}$ year control plants of $V$. jatamansi.

\begin{tabular}{|c|c|c|c|c|c|c|c|c|c|c|c|c|c|}
\hline S. No. & LN & AGFW & AGDW & BGFW & BGDW & $\mathrm{PH}$ & RL & LA & TPA & DPPHA & FRAPA & ABTSA & TPR \\
\hline $\mathrm{LN}$ & 1.00 & & & & & & & & & & & & \\
\hline AGFW & $0.49 * *$ & 1.00 & & & & & & & & & & & \\
\hline AGDW & $0.46^{*}$ & $0.85^{* *}$ & 1.00 & & & & & & & & & & \\
\hline BGFW & -0.09 & $0.42 *$ & $0.41 *$ & 1.00 & & & & & & & & & \\
\hline BGDW & -0.10 & $0.40^{*}$ & $0.39 *$ & $0.97 * *$ & 1.00 & & & & & & & & \\
\hline $\mathrm{PH}$ & 0.31 & $0.70^{* *}$ & $0.60 * *$ & $0.39^{*}$ & $0.42 *$ & 1.00 & & & & & & & \\
\hline RL & -0.10 & 0.03 & -0.00 & $0.55 * *$ & $0.63 * *$ & 0.17 & 1.00 & & & & & & \\
\hline LA & 0.07 & $0.61 * *$ & $0.54 * *$ & $0.51 * *$ & $0.47 * *$ & $0.62 * *$ & 0.21 & 1.00 & & & & & \\
\hline TPA & -0.16 & $-0.37 *$ & -0.30 & -0.13 & -0.08 & -0.21 & 0.33 & -0.19 & 1.00 & & & & \\
\hline DPPHA & -0.11 & $-0.36^{*}$ & -0.31 & -0.20 & -0.19 & -0.22 & 0.25 & -0.17 & $0.88^{* *}$ & 1.00 & & & \\
\hline FRAPA & -0.04 & -0.12 & -0.22 & -0.25 & -0.24 & -0.14 & -0.03 & 0.09 & $0.44 * *$ & $0.62 * *$ & 1.00 & & \\
\hline ABTSA & 0.02 & -0.17 & -0.18 & 0.17 & 0.13 & 0.09 & $0.39 *$ & 0.08 & 0.35 & $0.54 * *$ & 0.33 & 1.00 & \\
\hline TP R & -0.04 & -0.04 & 0.10 & 0.24 & 0.21 & 0.13 & 0.18 & 0.06 & -0.10 & -0.08 & -0.21 & -0.04 & 1.00 \\
\hline DPPHR & 0.10 & -0.09 & -0.01 & -0.27 & -0.22 & -0.14 & 0.03 & $-\overline{0.37 *}$ & 0.00 & -0.01 & -0.25 & -0.01 & 0.07 \\
\hline FRAPR & 0.30 & 0.01 & -0.08 & -0.17 & -0.14 & 0.07 & 0.09 & -0.16 & 0.29 & 0.18 & -0.12 & 0.09 & $-\overline{0.23}$ \\
\hline ABTSR & -0.23 & -0.13 & -0.03 & 0.12 & 0.10 & 0.10 & 0.07 & 0.06 & -0.01 & 0.03 & 0.10 & -0.07 & 0.82 \\
\hline
\end{tabular}

Level of significance: ${ }^{*} p<0.05$; ${ }^{*} p<0.01$. LN, Leaf Number; AGFW, above ground fresh weight; AGDW, above ground dry weight; BGFW, below ground fresh weight; BGDW, below ground dry weight; PH, plant height, LA; leaf area; RL, rhizome length; TPA, total phenolics in aerial portion; DPPHA, DPPH activity in aerial portion; FRAPA, FRAP activity in aerial portion; ABTSA,ABTS activity in aerial portion; TPR, Total phenolics in root portion; DPPHR, DPPH activity in root portion; FRAPR, FRAP activity in root portion; ABTSR, ABTS activity in root portion.

Table 4. Relationship (Pearson Correlation) among morphological and phytochemical parameters of $1^{\text {st }}$ year

\begin{tabular}{|c|c|c|c|c|c|c|c|c|c|c|c|c|c|c|c|c|}
\hline S. No & $\mathrm{LN}$ & AGFW & AGDW & BGFW & BGDW & PH & RL & LA & TPA & DPPHA & FRAPA & ABTSA & TPR & DPPHR & FRAPR & BTSR \\
\hline $\mathrm{LN}$ & 1.00 & & & & & & & & & & & & & & & \\
\hline AGFW & $0.63 * *$ & 1.00 & & & & & & & & & & & & & & \\
\hline AGDW & $0.41^{*}$ & $0.66^{* * *}$ & 1.00 & & & & & & & & & & & & & \\
\hline BGFW & $0.42 *$ & $0.82 * *$ & $0.60 * *$ & 1.00 & & & & & & & & & & & & \\
\hline BGDW & 0.35 & $0.78 * *$ & $0.60 * *$ & $0.90 * *$ & 1.00 & & & & & & & & & & & \\
\hline PH & 0.25 & $0.62 * *$ & $0.44 *$ & $0.52 * *$ & $0.43 *$ & 1.00 & & & & & & & & & & \\
\hline RL & 0.10 & 0.08 & 0.06 & 0.36 & 0.29 & 0.06 & 1.00 & & & & & & & & & \\
\hline LA & $0.51^{* *}$ & $0.65 * *$ & $0.45^{*}$ & $0.57 * *$ & $0.58^{* *}$ & $0.53 * *$ & 0.35 & 1.00 & & & & & & & & \\
\hline TP A & 0.01 & 0.04 & -0.05 & 0.10 & 0.13 & 0.07 & 0.35 & 0.04 & 1.00 & & & & & & & \\
\hline DPPHA & -0.03 & 0.03 & -0.18 & 0.07 & 0.08 & -0.14 & 0.01 & 0.02 & 0.22 & 1.00 & & & & & & \\
\hline FRAPA & -0.05 & 0.02 & -0.02 & 0.04 & 0.16 & 0.03 & -0.01 & $\begin{array}{c}- \\
0.02\end{array}$ & $0.66^{* *}$ & -0.05 & 1.00 & & & & & \\
\hline ABTSA & -0.27 & -0.26 & -0.04 & -0.24 & -0.19 & -0.08 & -0.03 & $\overline{-}$ & -0.10 & 0.13 & -0.05 & 1.00 & & & & \\
\hline TPR & -0.27 & -0.12 & 0.18 & 0.02 & 0.11 & 0.08 & $0.37 *$ & 0.14 & $0.37 *$ & 0.09 & 0.15 & -0.12 & 1.00 & & & \\
\hline DPPHR & -0.31 & -0.18 & 0.06 & -0.04 & -0.08 & 0.01 & 0.28 & 0.01 & 0.27 & 0.02 & 0.01 & -0.09 & $0.80 * *$ & 1.00 & & \\
\hline $\begin{array}{l}\text { FRAP } \\
\text { R }\end{array}$ & -0.38 & -0.34 & -0.04 & -0.06 & -0.06 & -0.07 & $0.44 *$ & 0.01 & 0.25 & 0.05 & 0.02 & -0.00 & $0.72 * *$ & $0.80^{* *}$ & 1.00 & \\
\hline ABTSR & -0.18 & -0.05 & -0.23 & 0.21 & 0.13 & -0.02 & $0.41 *$ & 0.02 & $0.53 * *$ & $0.58 * *$ & 0.19 & 0.09 & 0.14 & 0.05 & 0.18 & 1.00 \\
\hline
\end{tabular}

Level of significance: * $p<0.05 ; * *<<0.01$. LN, Leaf Number; AGFW, above ground fresh weight; AGDW, above ground dry weight; BGFW, below ground fresh weight; BGDW, below ground dry weight; PH, plant height, LA; leaf area; RL, rhizome length; TPA, total phenolics in aerial portion DPPHA, DPPH activity in aerial portion FRAPA, FRAP activity in aerial portion; ABTSA,ABTS activity in aerial portion; TPR, Total phenolics in root portion; DPPHR, DPPH activity in root portion; FRAPR, FRAP activity in root portion; ABTSR, ABTS activity in root portion. 


\section{Discussion}

The higher levels of phenolics, tannins, and the antioxidant and PAL activity in $V$. jatamansi, following AMF treatment, correspond well with the report of increased production of phytochemicals due to infection of AMF (Toussaint et al., 2008). The study on the association of AMF with a cultivar of lettuce (Batavia Rubia Munguia) revealed that accumulation of phenolics in leaves increased significantly under optimal irrigation (Baslam and Goicoechea, 2012). In another species of Valeriana ( $V$. officinalis) enhanced secondary metabolite (sesquiterpenic acids) production has been observed after mycorrhizal inoculation along with a decrease in plant biomass; the nutritional improvement in such treated plants, in general, resulted in positive growth response (Nell et al., 2010). The root portion of the plant seems to be an important factor for the production of active ingredients and products of pharmaceutical importance. Several reports on medicinal and aromatic plants confirm increased phosphorus content and biomass in AMF treated plants (Khaosaad et al., 2006). The observed reduction in biomass related parameters of the $1^{\text {st }}$ year plants, treated with AMF, agreed with earlier reports and suggested that the AMF association negatively influences or independent of biomass production (Hausmann and Hawkes, 2010). This, however, does not follow the general observation of increased biomass production following treatments (Smith and Read, 2008). Further, clear trends of increased value of morphological parameters were observed following $2^{\text {nd }}$ year growth, except for BGDW. This is supported by reports on other medicinal plants (Khaosaad et al., 2006).

A large number of studies have shown that growth responses to AMF colonization depend both on the host plant and fungal species, as well as on the experimental conditions (Huang et al., 2013). Evidences indicate that AMF induce changes in the primary me- tabolism, including photosynthesis, water uptake and drought tolerance (Ruiz-Lozano, 2003). Changes in secondary metabolism such as phytohormone dynamics, structural modifications and activation of defense mechanism were also reported in Bounteloua gracilis and Ocimum basilicum (Allen et al., 1982).

Increased phenolics, tannins, phenolic composition and antioxidant activity in AMF treated $1^{\text {st }}$ year plants can be explained in terms of defense response to fungal infection. Further, the higher antioxidant activity of the samples from treated plants appears to be on account of higher content of phenolics and tannin which are known to exhibit positive relationship with antioxidant activity (Bhatt et al., 2012). As such, antioxidant properties of phenolic compounds play a vital role in the defense mechanism of biological systems (Macheix and Fleuriet, 1998). In the present study also total phenolics exhibited significant positive correlation with antioxidant activity in treated as well as control plants. Earlier reports also indicated that the antioxidant potential of medicinal plants may be related to the concentration of phenolic compounds which include phenolic acid, flavonoids, anthocyanins and tannins (Bhatt et al., 2012; Jugran et al., 2013). These compounds are of great value in preventing the onset and/or progression of many human diseases (Muanda et al., 2009). Antioxidative enzymes in leaves of pepper indicated that AMF ( Glomus deserticola) can alleviate the deleterious effect of Verticillium dahliae on the growth and yield of plant during pathogen attacks (Garmendia et al., 2004). Moreover, the high phytochemical content in AMF treated plants could be associated with induction of PAL activity following exposure of plants with AMF for the first time, and thereby resulting in higher production of secondary metabolites. However, no further increase in activity after $1^{\text {st }}$ year would indicate possible adaptation of plants after the first exposure. The observed increase in PAL activity levels in fresh aerial and root parts might have resulted in increased phenolic 
content and antioxidant activity in treated plants. Study on the mycorrhizal treated plants of tomato has also shown increased growth, PAL activity, phenol concentration and foliar trichome density as compared to control plants (Kapoor, 2008).

\section{Conclusions}

Present study provides evidence that AMF inoculation can be a simple and useful method for obtaining higher content of phenolics tannins and phenolic composition, and consequently increased antioxidant activity in $\mathrm{V}$. jatamansi. As the species is facing ever increasing demand for quality herbal products, the situation necessitates standardization of methods for obtaining adequate raw material for pharmaceutical purposes and to minimize pressure on natural populations by way of promoting cultivation. The production of higher yield and quality in medicinal plants, through conventional methods, often requires external inputs such as fertilizers and pesticides. In this context, use of mycorrhizal inoculation, a natural alternative to chemical fertilizers, is likely to boost the production of active ingredients. In this study clear cut growth and enhancement were recorded in morphological and phytochemical attributes, which indicate that AMF can be utilized for higher biomass production as well as for the higher production of antioxidants and phenolics. The use of AMF could thus be recommended as a part of the package of practice for growers.

\section{Acknowledgements}

We thanks Director of the Institute for providing facilities. All colleagues of Biodiversity Conservation \& Management Theme are thanked for cooperation and help during the study. AJ thanks Dr. G.N. Mohan Kumar, Associate Professor, Washington State University, USA for helping in standardization of PAL assay. Financial support from the Ministry of Environment \& Forests, GOI for in house project (No. 10 - GBPIHED) is duly acknowledged. The AMF preparation, used in the study was a gift from Prof. Yudhvir K. Bhoon, Sri Venkateswara College, New Delhi and the detail information provided by Prof. Alok Adholeya, The Energy and Resource Institute, New Delhi is greatly acknowledged.

\section{References}

Allen, M.F., Moore, T.S., Christensen, M. 1980. Phytohormone changes in Bouteloua gracilis infected by vesicular-arbuscular mycorrhizae. I: Cytokinin increases in the host plant. Can. J. Bot. 58, 371-374.

Allen, M.F., Moore, T.S., Christensen, M. 1982. Phytohormone changes in Bouteloua gracilis infected by vesicular-arbuscular mycorrhizae. II: Altered levels of gibberellin- like substances and abscisic acid in the host plant. Can. J. Bot. 60, 468-471.

Banuelos J., Alarcón A., Larsen J., Cruz-Sánchez S., Trejo D. 2014. Interactions between arbuscular mycorrhizal fungi and Meloidogyne incognita in the ornamental plant Impatiens Balsamina. J. Soil Sci. Plant Nutri. 14, 63-74.

Baslam, M., Garmendia, I., Goicoechea, N. 2013. Enhanced Accumulation of Vitamins, Nutraceuticals and Minerals in Lettuces Associated with Arbuscular Mycorrhizal Fungi (AMF): A Question of Interest for Both Vegetables and Humans. Agriculture 3, 188-209.

Baslam, M., Goicoechea, N. 2012. Water deficit improved the capacity of arbuscular mycorrhizal fungi (AMF) for inducing the accumulation of antioxidant compounds in lettuce leaves. Mycorrhiza. 22, 347-359.

Bhatt, I.D., Dauthal, P., Rawat, S., Gaira, K.S., Jugran, A., Rawal, R.S., Dhar, U. 2012. Characterization of essential oil composition, phenolic content, and antioxidant properties in wild and planted individuals of Valeriana jatamansi Jones. Sci. Horticult. 136, 61-68. 
Brand-William, W., Cuveiler, M.E., Berset, C. 1995. Use of free radical method to evaluate antioxidant activity. LWT-Food Sci. Technol. 28, 2530.

Cai, Y., Luo, Q., Sun, M., Corke, H. 2004. Antioxidant activity and phenolic compounds in 112 traditional Chinese medicinal plants associated with anticancer. Life Sci. 75, 2157-2184.

Caporale A.G., Sarkar D., Datta R., Punamiya P., Violante A. 2014. Effect of arbuscular mycorrhizal fungi (Glomus spp.) on growth and arsenic uptake of vetiver grass (Chrysopogon zizanioides L.) from contaminated soil and water systems. J. Soil Sci. Plant Nutri. 14. 955-972.

Cavagnaro, T.R., Smith, F.A., Lormer, M.F., Haskard, K.A., Ayling, S.M., Smith, S.E. 2001. Quantative development of Paris-type arbuscular mycorrhizas formed between Asphodelus fistulosus and Glomus coronatum. New Phytol. 149, 105-113.

Channabasava, A., Lakshman, H.C., Jorquera, M.A. 2015. Effect of fungicides on association of arbuscular mycorrhiza fungus rhizophagus fasciculatus and growth of proso millet (panicum miliaceum). J. Soil Sci. Plant Nutr. 15, 35-45.

Faria, A., Oliveira, J., Neves, P., Gamerio, P. SantosBuelga, C., de Freitas, V., Mateus, N., 2005. Antioxidant properties of prepared blueberry ( $\mathrm{Vac}$ cinium myrtillus) extracts. J. Agric. Food Chem. 53, 6896-6902.

Garmendia, I., Goicoechea, N., Aguirreolea, J. 2004. Antioxidant metabolism in asymptomatic leaves of Verticillium-infected Pepper associated with an arbuscular mycorrhizal fungus. J. Phytopathol. 152, 593-599.

Hausmann, N.T., Hawkes, C.V. 2010. Order of plant host establishment alters the composition of arbuscular mycorrhizal communities. Ecology. 91, 2333-2343.
Huang, J.C., Lai, W.A., Singh, S., Hameed, A., Young, C.C. 2013. Response of mycorrhizal hybrid tomato cultivars under saline stress. J. Soil Sci. Plant Nutr. 13, 469-484.

Jugran, A., Rawat, S., Dauthal, P., Mondal, S., Bhatt, I.D., Rawal, R.S. 2013. Association of ISSR markers with some biochemical traits of Valeriana jatamansi .Jones. Ind. Crop Prod. 44, 671676.

Kalim, M.D., Bhattacharyya, D., Banerjee, A., Chattopadhyay, S. 2010. Oxidative DNA damage preventive activity and antioxidant potential of plants used in Unani system of medicine. BMC Compl. Alt. Med. 10,77.

Kapoor, R. 2008. Induced resistance in mycorrhizal tomato is correlated to concentration of Jasmonic Acid. J. Biol. Sci. 8, 49-56.

Khaosaad, T., Vierheilig, H., Nell, M., Zitterl-Eglseer, K., Novak, J. 2006. Arbuscular mycorrhiza alter the concentration of essential oils in oregano (Origanum sp., Lamiaceae). Mycorrhiza. 16, 443-446.

Macheix, J, Fleuriet. 1998. Flavonoids in health and diseases. Marcel Dekker Inc. New York, pp 839868.

Muanda. F., Kone, D., Dicko, A., Soulimani, R., Younos, C. 2009. Phytochemical composition and antioxidant capacity of three Malian medicinal plant parts. eCAM; doi: 10.1093/ecam/nep109.

Nell, M., Wawrosch, C., Steinkellner, S., Vierheilig, H., Kopp, B., Losse, A., Franz, C., Novak, J., Zittere - Eyeseer, K. 2010. Root colonization by symbiotic arbuscular mycorrhizal fungi increases sesquiterpenic acid concentration in Valeriana officinalis L. Planta Med.76, 393-398.

Nwinuka, N.M., Ibeh, G.O., Ekeke, G.I. 2005. Proximate composition and levels of some toxicants in four commonly consumed species. J. Applied Sci. Environ. Management 9,150-155. 
Petersen, M., Simmonds, M.S.J. 2003. Rosmarinic acid. Phytochemistry. 62, 121-125.

Rhodes, M. 1985. The physiological significance of plant phenolic compounds. Ann. Proceed. Phytochem. Soc. Europe. 25, 99-118.

Ruiz-Lozano, J.M. 2003. Arbuscular mycorrhizal symbiosis and alleviation of osmotic stress. New perspectives for molecular studies. Mycorrhiza. 3, 309-317.

Schadt, C.W., Mullen, R.B., Schmidt, S.K. 2001. Isolation and phylogenetic identification of a darkseptate fungus associated with the alpine plant Ranunculus adoneus. New Phytol. 150, 747-755.

Singleton, V.L., Rossi, J.A. 1965. Colorimetry of total phenolics with phosphomolybdic-phosphotungstic acid reagents. American J. Enol. Vitic. 16, 144-158.

Smith, S.E., Read, D.J. 2008. Mycorrhizal symbiosis, $3^{\text {rd }}$ edition. London, UK: Academic Press.

Tiwari, P., Adholeya, A. 2002. In vitro co-culture of two AMF isolates Gigaspora margarita and Glomus intraradices on Ri T-DNA transformed roots. FEMS Microbiol. Lett. 206, 39-43.
Toussaint, J.P., Kraml, M., Nell, M., Smith, S.E., Smith, F.A., Steinkellner, S., Schmiderer, C., Vierheilig, H., Novak, J. 2008. Effect of Glomus mosseaeon concentrations of rosmarinic and caffeic acids and essential oil compounds in basil inoculated with Fusarium oxysporum f. sp. basilici. Plant Pathol. pp. 1109-1116.

Toussaint, J.P., Starnaud, M., Charest, C. 2004. Nitrogen transfer assimilation between the arbuscular mycorrhizal fungus Glomus intaradices Schenck \& Smith and Ri DNA roots of Dacus carrota L. in an in vitro compartmented system. Can. J. Microbiol. 50, 251-260.

Zhi-Lin, Y., Chuan-Chao, D., Lian-Quing, C. 2007. Regulation and accumulation of secondary me tabolites in plant-fungus symbiotic system. African J. Biotechnol. 6, 1266-1271.

Zucker, M. 1968. Sequential induction of phenylalanine ammonia lyase and a lyase inactivation system in potato tuber disks. Plant Physiol. 43, 365-374. 